\title{
O BLOGUEIRO COMO REPRESENTAÇÃO DA CONTEMPORANEIDADE
} THE BLOGGER AS REPRESENTATION OF CONTEMPORANEOUSNESS

\section{EL BLOGUEIRO REPRESENTACIÓN DE LO CONTEMPORANEIDAD}

\author{
Fernando Moreno da Silva ${ }^{1}$ \\ Arnaldo Cortina ${ }^{2}$
}

\section{RESUMO:}

O presente artigo tem como objetivo analisar a caracterização do blogueiro e, por conseqüência, a imagem do homem contemporâneo, afinal, a prática do blogueiro é uma extensão das tendências da contemporaneidade, uma amostra do comportamento inserida naquilo que vem sendo chamado de pós-modernismo. A análise do trabalho chega à conclusão de que o internauta, assim como o homem contemporâneo, é definido por três pilares: narcisismo, pseudoliberdade e ludicidade.

Palavras-chave: Blogueiro; contemporaneidade; pós-modernismo.

\section{ABSTRACT:}

This article aims to analyze the characterization of the blogger and, consequently, the image of the contemporary man; after all, the practice of the blogger is an extension of contemporary trends, a sample of the behavior included in what is being called post-modernism. After the analysis of the work, the conclusion is that the blogger, as well as the contemporary man, is defined by three pillars: narcissism, pseudo liberty and fun.

Keywords: Blogger; contemporary; post-modernism.

\section{RESUMEN:}

Este artículo tiene por objetivo analizar la caracterización de los bloggers y, por consiguiente, la imagen del hombre contemporáneo, después de todo, la práctica del blogger es una extensión de las tendencias contemporáneas, una muestra de comportamiento que lo que se llama posmodernismo incluye. El análisis de la obra

\footnotetext{
${ }^{1}$ Doutor em Lingüística e Língua Portuguesa pela UNESP/Araraquara- SP, Mestre em Lingüística e Língua Portuguesa pela UNESP/Araraquara- SP e Graduação em Jornalismo pela UNESP/Bauru SP.

2 Livre-Docente em Semiótica na UNESP-FCL/CAr, 2006, Pós-Doutor (Projeto de pesquisa: "História da Leitura no Brasil"), na Université de Limoges, Limoges-França, 2001-2002. Doutor em Letras área de Lingüística pela FFLCH-USP, Mestre em Letras - área de Lingüística pela FFLCH-USP, docente do Departamento de Lingüística da Faculdade de Ciências e Letras da UNESP/AraraquaraSP.
}

R. Inter. Interdisc. INTERthesis, Florianópolis, v.6, n.2, p. 161-190, jul./dez. 2009 
llega a la conclusión de que el internauta, así como el hombre contemporáneo, es definido por tres pilares: narcisismo, seudo libertad y diversión.

Palabras-clave: Blogger; contemporaneidad; posmodernismo.

\section{BALANÇO DA CONTEMPORANEIDADE}

O tripé, suporte portátil com três pés, sobre o qual podemos pôr um aparelho, serviu como base para sustentação de várias teorias. Charles Peirce, Ogden e Richards, Umberto Eco, Ferdinand de Saussure: estas são apenas algumas figuras ilustres da história cultural que se valeram da relação triádica para estruturar suas idéias.

Vou apropriar-me desta figura emblemática para mostrar que blogueiro pode ser definido pela conjunção do trinômio "narcisismo-pseudoliberdade-ludicidade".

Pode parecer uma ousadia três palavras traçarem uns raios $X$ do comportamento humano nessa contemporaneidade. Ousadia porque o ser humano é dotado de uma profundeza inatingível, obscura, onde se escondem experiências vividas, sonhos, desejos, medo, dores, incertezas. "Tudo isso é intangível, e seus contornos apenas podem ser intuídos ocasionalmente, como um clarão que subitamente reluz e logo se esvai, entrevisto de maneira enviesada, turva, confusa, seja por acaso ou após um árduo trabalho de introspecção. (SIBILIA, 2005, p. 36). Desvendar sua volatibilidade não é tarefa nada fácil. Kaspar Hauser (O ENIGMA, 1974), ao observar um músico tocando piano, diz: "Por que tudo é tão difícil para mim? Por que não posso tocar piano como respiro?". Ora, não só Hauser tem dificuldade para apreender. A ciência, com todo seu aparato e herança, até hoje não conseguiu alcançar, com objetividade, a natureza humana por completo. E nunca o conseguirá.

O ser humano é como um oceano: apresenta uma superfície visível e esconde uma profundidade absolutamente inatingível. Toda tentativa de tipificá-lo é um mero lenitivo, uma necessidade que nos traz um alívio. Assim procedendo, apalpando um corpo que fingimos existir, escamoteamos um conhecimento que queremos desconhecer: jamais conheceremos a nós próprios, pois somos um ser atravessando uma neblima, como Édipo na mão do destino.

R. Inter. Interdisc. INTERthesis, Florianópolis, v.6, n.2, p. 161-190, jul./dez. 2009 
Karl Gustav Jung (1981), para quem a mitologia era projeção da consciência coletiva, diz-nos que a mitologia nos leva a um ponto: quem somos?

Destarte, muito mais que a luta inglória da vontade humana contra os desígnios do destino, a tragédia sofocliana nos denotou que vivemos uma eterna busca de nossa própria identidade.

Enfim, embora a obscuridade impere no homem, isso não nos priva da tentativa de delineá-lo. Como dizia Maria Quintana (1982, p. 47), "se as coisas são inatingíveis... ora! Não é motivo para não querê-las".

\section{NARCISISMO}

Rachel Pacheco, 21 anos. Este é apenas um nome qualquer de uma mulher. Certamente ninguém a conhecerá. Mas se o troco por Bruna Surfistinha, nome pelo qual responde Raquel, sem dúvida sobrevém a história da garota de programa que virou fenômeno da internet através de seu blog, criado em 2003, que revela suas aventuras sexuais e os bastidores da prostituição.

Depois do sucesso na internet, com seu blog entre os mais acessados da blogosfera e dezenas de comunidades no Orkut (site com comunidades virtuais), Bruna Surfistinha repetiu a fama no mercado editorial. Seu livro, $O$ doce veneno do escorpião, um gênero de não-ficção narrativa que relata em detalhes sua vida de prostituta e várias de suas intimidades, teve sua primeira tiragem, de $10 \mathrm{mil}$ exemplares, esgotada em duas semanas.

Mas o caso de Bruna Surfistinha não é o único na internet. Não raro, vemos estampadas nos principais jornais manchetes de exposição de jovens na rede mundial de computadores: Adolescentes expõem corpos em fotologs na busca de fama virtual (TÓFOLI, 2006, p. C4). Neste último caso, o jornal noticia a apelação inescrupulosa dos adolescentes, que se mostram na rede em fotos ousadas para atrair visitantes para seus blogs. Diz uma das jovens, de apenas 15 anos de idade: "Adoro me fotografar, mas resolvi ter um fotolog porque todo mundo tem. Não existe menina do colegial que não tenha seu fotolog hoje. É uma questão de necessidade mesmo". Mais à frente, a adolescente reclama de seu irmão: "Ele tem ciúme e reclama das imagens, mas explico que a concorrência está grande". Na mesma

R. Inter. Interdisc. INTERthesis, Florianópolis, v.6, n.2, p. 161-190, jul./dez. 2009 
matéria, outra jovem, de 14 anos, pede aos internautas que adicionem seu fotolog para ajudá-la a se tornar mais popular.

Esses casos nos revelam um comportamento curioso. Denunciam uma tendência que grassa vertiginosamente nos meios de comunicação, e agora nos blogs. Por que tanto sacrifício e apelação para alcançar tanta popularidade? Na TV, são programas que exibem corpos femininos seminus; na internet, nosso foco, são blogs e fotologs que expõem intimidades e textos com baixo calão.

De acordo com o balanço anual de 2008 divulgado pelo Technorati (serviços norte-americano que estuda a blogosfera), as razões que levam as pessoas a blogarem são a auto-expressão, constatando, apesar da variedade, que o tema preferido entre os blogueiros é a temática pessoal. $O$ estudo revela que o sucesso do blogueiro é medido, sobretudo, pela satisfação pessoal (75\%), pelo número de comentários (58\%) e pelo número de visitantes (53\%), entre outros parâmetros. 0 estudo ainda revela que $54 \%$ dos blogueiros profissionais, como Noblat, usam o blog como vitrine profissional, pois afirmam que tiveram reconhecimento maior em seu trabalho depois que começaram a blogar.

Isso nos leva a crer que o blog é uma mídia do "eu". Portanto, para a indagação sobre a exposição pessoal de escacha, como resposta apresentamos o narcisismo. Conforme estamos vendo, um fato; e como veremos, uma necessidade humana. Não creio que narcisismo seja uma tendência; é, ao contrário, um fenômeno permanentemente intrínseco ao ser humano, como exporemos à frente.

Tomo-o não no sentido freudiano, que se refere à antítese entre os investimentos no próprio "eu" (a libido do ego) e os investimentos nos outros (a libido objetal). O sentido de que me aproprio é para discorrer sobre o desejo de se ver pelo outro, ou seja, buscar conhecer-se ou se validar através do olhar do outro.

\subsection{0 pássaro vaidoso}

O insight para falar do narcisismo não proveio tão-somente da observação dos blogs. Descendeu inicialmente do comportamento animal, numa dádiva recebida da natureza, quando um pássaro predestinadamente resolveu se simpatizar com o retrovisor de meu veículo, estacionado em frente a minha casa.

R. Inter. Interdisc. INTERthesis, Florianópolis, v.6, n.2, p. 161-190, jul./dez. 2009 
Estando eu sentado na área frontal, pude observar o comportamento do pássaro diante do espelho. A situação pela qual passou o pássaro foi muito semelhante a de Narciso, personagem mitológico que inspirou a cunhagem do termo "narcisismo". Na mitologia grega, Narciso era filho do deus Céfiso, protetor do rio Céfiso, e da ninfa Liríopeo. Era um jovem de extrema beleza, que despertava o amor de várias ninfas. Dentre elas, estava Eco, que, depois de rejeitada por Narciso, implorou à deusa Nêmesis que vingasse esse desprezo. E Narciso recebeu o troco com a mesma moeda. Ao ver seu rosto refletido nas águas de um lago, a exemplo de Eco, apaixonou-se desesperadamente, mas por sua própria imagem. Paralisado, arrebatado de paixão, admira sua própria imagem e logo se vê impedido de desfrutá-la. Diante da agonia de não poder realizar seu desejo, morre, transformando-se numa flor, a flor de Narciso.

O pássaro, assim como Narciso, parece que também gostou de sua imagem. Ao ver-se no espelho do retrovisor, o pássaro se deteve, ficando ali, sem exagero, por volta de meia hora. Ele bicava o espelho e olhava, olhava, olhava. Virava, mexiase e olhava, olhava, olhava. Nesse ínterim, talvez em três ou quatro vezes, o pássaro voava para se assentar próximo. Em seguida, voltava e repetia a mesma cena: bicava o espelho sem se cansar.

Se para o pássaro observar sua própria imagem - deixemos de lado a discussão se o pássaro tinha consciência ou não de sua imagem - era curioso ou fascinante, para nós, humanos, olhar-se pode igualmente sê-lo.

Quem não se encanta, ou se decepciona, quando se vê numa filmagem doméstica, no âmbito familiar? Se for aparecer numa emissora de TV em um programa jornalístico, depois de conceder uma entrevista, nem pisca na frente do televisor, ansioso para ouvir e ver suas declarações. É natural para o ser humano, talvez tenha sido para o pássaro, ver-se, alimentar sua imagem pelo outro.

\subsection{Necessidades humanas}

O homem, como veremos no item "liberdade", em virtude de suas funções fisiológicas, pertence ao reino animal. Necessita, pois, satisfazer suas necessidades fisiológicas: fome, sede, sexo, etc. Na medida em que o homem é humanizado, suas

R. Inter. Interdisc. INTERthesis, Florianópolis, v.6, n.2, p. 161-190, jul./dez. 2009 
necessidades instintivas não são suficientes para torná-lo feliz, porque descobre outras maravilhas a partir da convivência com a realidade.

Após satisfazer suas necessidade animais, ele é impulsionado por suas necessidades humanas. Segundo Fromm (1961), as necessidades que se originam da existência humana são cinco: (i) relação: relacionar-se com o outro; (ii) transcendência: impulso de transcender o papel de criatura, um ser passivo deste mundo, para se tornar criador, responsável por seu próprio destino; (iii) arraigamento: o laço mais básico e natural é o vínculo da criança com a mãe; (iv) identidade: a consciência de si mesmo a partir do desprendimento de um grupo rumo ao processo de individualização; (v) orientação: a necessidade de se apoiar em alguma coisa, independentemente de ser falsa ou verdadeira, mas capaz de situá-lo no mundo.

O sacrifício para alcançar a popularidade na internet, como nos casos descritos acima, advém sobremaneira dessa necessidade humana chamada narcisismo.

Se ser celebridade é ser um mito, um modelo imitável, que traz consequentemente satisfação, esta com certeza seria escassa, porque adentrar no Monte Olimpo, como chamou a mídia Morin (1997), não estaria ao alcance de qualquer um. Mas o blog proporcionou a esse "qualquer um" - mesmo àquele que não domina a informática, basta conhecer um pouco de internet - a morada no novo Monte Olimpo.

Se o jornal e depois a televisão são os grandes veículos da notoriedade, neste século o blog desponta timidamente como um assoprador da vaidade humana. Mostrar quem sou, ainda que de forma apelativa, alcançar popularidade ou audiência é uma panacéia para encobrir a frustração do anonimato, do ostracismo.

A busca desenfreada pelo sucesso e pela audiência é explicada pela Psicologia como o preenchimento de uma falta qualquer, um álibi para apagar uma dor ou uma falta. Qualquer tipo de ação apelativa, ainda que humilhante ou vil, seria aquilo que Freud (1996) chama de "atos sintomáticos". São ações determinadas pelo inconsciente que desempenham o papel de sintomas.

Ser visto pelo grande público é fugir à vida ordinariamente estafante. $O$ homem tenta fugir da dádiva recebida - a razão, que lhe dá consciência de sua R. Inter. Interdisc. INTERthesis, Florianópolis, v.6, n.2, p. 161-190, jul./dez. 2009 
pequenez e impotência - alentando a transcendência da qual nos fala Fromm (1961). Uma evasão que busca resolver uma insatisfação com a vida, buscar sair do hic et nunc. Se se ocupar dos detalhes da vida de uma celebridade famosa era um eficiente exercício de fuga da própria realidade, a mesma fuga permanece, mas agora promovendo a si próprio. Não é preciso buscar o entretenimento, porque a própria vida se tornou ela mesma um entretenimento.

Com uma sociedade centrada em convenções e regras, quem se desvia indubitavelmente causará estranheza. Assim nos diz Bergson (1983, p. 99-100), que deu ao riso a função social de corrigir as infrações da sociedade, ao revelar os defeitos: "O riso é, antes de tudo, um castigo. Feito para humilhar, deve causar à vítima dele uma impressão penosa. A sociedade vinga-se através do riso das liberdades que se tomaram com ela.". Com esse perfil corretivo, o riso é ambivalente; ao mesmo tempo conservador e subversivo. Conservador, quando defende a norma e a regra, ridicularizando tudo que contraria a visão de mundo do padrão vigente; progressista, no instante em que critica padrões ultrapassados, não condizentes com as necessidades do momento.

Mas a Antropologia nos diz que enfatizar as particularidades da vida, nossa intimidade, também é inato ao comportamento humano. Sob a ótica antropológica (VELHO, 2004), há uma permanente convivência da contradição entre a particularização de experiências restritas de certos grupos (como os blogueiros) e a universalização de experiência que se expressam de conjuntos homogeneizados. Esse acaba sendo o grande problema da cultura, impasse este que, quando não resolvido, provoca uma tensão capaz de gerar, como consequência, um afastamento do indivíduo. O rompimento nem sempre é amistoso, porque o dissidente sofre com o controle social, com a incompreensão. Mas, por outro lado, aquele que sai das normas, o desviante, pode se transformar num marco delimitador, um símbolo de identidade. Não é à toa que na internet se proliferam assustadoramente não só as páginas de blog, de diferentes formas e temas, mas também as outras comunidades virtuais, como o Orkut, através do qual internautas compartilham os mesmos ídolos, as mesmas músicas, os mesmos estudos, os mesmos sonhos...

Com a particularização de experiências e a intimidade temos o processo de individualização, mas não blogueiros individualistas. Ao invés de individualistas,

R. Inter. Interdisc. INTERthesis, Florianópolis, v.6, n.2, p. 161-190, jul./dez. 2009 
temos blogueiros narcisistas. O individualista vê o mundo como um vácuo a ser preenchido segundo seus próprios desejos. O narcisista, ao contrário, vê o mundo como um espelho, pois necessita do olhar do outro para validar sua imagem, seu comportamento, seu valor. Lasch (1983), n'A cultura do narcisismo, já havia ressaltado a ação narcisista do homem contemporâneo: "Não obstante suas ocasionais ilusões de onipotência, o narcisista depende de outros para validar sua auto-estima. Ele não consegue viver sem uma audiência que o admire." (p. 30)

Até mesmo n'A insustentável leveza do ser aparece o fenômeno do olhar do "eu" no outro: "Todos nós temos a necessidade de ser olhados" (KUNDERA, 1985, p.271). O livro apresenta quatro categorias dentro das quais o homem pode ser classificado, dependendo do olhar sob o qual queremos viver: quem procura o olhar de um número infinito de pessoas anônimas; aqueles que não podem viver sem o foco de numerosos olhos familiares; aqueles que têm necessidade de viver sob o olhar do ser amado; e, a mais rara, aqueles que vivem sob o olhar imaginário dos ausentes. No caso do blogueiro, ele se encaixaria melhor na primeira categoria, pois vive à sombra de uma miríade de pessoas sobre as quais não tem a mínima noção de quem seja, a não ser o eventual conhecimento de seu pseudônimo. De dentro de sua casa, sem contato físico algum, ele tem a possibilidade de se comunicar com milhares de pessoas por dia sem ter a mínima noção de quem sejam seus interlocutores, e estes da mesma forma em relação a ele.

\subsection{Complexo do espelho, espelho meu}

O estado de insegurança ou dúvida do blogueiro só é desfeito quando vê seu "eu grandioso" refletido nas pessoas. Aqui está o grande problema da atualidade. Se nosso valor está exposto aos olhos de todos, a incompletude sempre imperará, porque queremos continuamente impressionar. Aí reside a insegurança das pessoas, que ficam permanentemente preocupadas não com seus pensamentos, mas com que os outros pensam delas. O indivíduo não mais se define pelo que ele é através de sua interioridade. Define-se por aquilo que o outro julga nele. Daí uma cultura narcisista, impregnada pelo que chamo de Complexo do espelho, espelho meu.

R. Inter. Interdisc. INTERthesis, Florianópolis, v.6, n.2, p. 161-190, jul./dez. 2009 
Para enfatizar o que havíamos colocado anteriormente, a bulimia de fama do blogueiro, caracterizada como "ato sintomático" para o preenchimento de uma falta ou para apagar uma dor, revela a dependência em relação ao outro por meio do anátema desse complexo. Ele é uma forma de ilustrar o conceito de narcisismo, tomando como fonte os contos do Irmãos Grimm. Em Branca de Neve (GRIMM, 1998), a rainha possuía um espelho mágico para o qual perguntava todos os dias: "Espelho, espelho meu! Há no mundo alguém mais bela do que eu?" A madrasta feiticeira necessitava da resposta do espelho para se sentir realmente bela. Sua própria opinião não bastava. Precisava dele para completá-la. A mesma insegurança da qual sofria a rainha sofre o blogueiro. Esse é o complexo que o envolve: para existir, para validar a si próprio, ele se torna dependente do outro.

Ser respaldado pelo outro é uma espécie de terapia. Traz alívio, preenche um vazio. No catolicismo, a confissão a que os padres submetem os fiéis não deixa de ser positiva, porque traz tranquilidade e apaga o temor de quem confessa. $\mathrm{O} \mathrm{Dr}$. Joseph Breuer (QUANDO, 2007), professor de Freud, estava convicto de que desabafar cura. Seu método da "cura através da fala", ironizada pela expressão "limpeza pela chaminé", trouxe bons resultados para seus pacientes. E foi esse método que muito influenciou Freud, depois da hipnose, ao tratamento no divã.

\subsection{Princípio da exotopia}

O psicanalista francês Jacques Lacan (1901-1981), com a "teoria do espelho", ensina-nos que construímos nossa identidade a partir do Outro (nomenclatura convencionada em maiúsculo por Lacan). Dessa forma, conhecemo-nos através do Outro.

Esse, inclusive, é o princípio da exotopia, ou excedente de visão estética, a que se refere Bakhtin (1997). Eu me completo por meio da visão do outro, porque a percepção que tenho de mim mesmo é parcial. A percepção que tenho do outro, ao contrário, é completa, porquanto posso percebê-lo por inteiro. Essa posição exterior, esse olhar do outro sobre mim, que pode me completar, dando-me um acabamento. Dependendo do ângulo em que me encontro, somente o outro pode me ver, justamente onde não posso alcançar minha visão. "Por mais perto de mim que

R. Inter. Interdisc. INTERthesis, Florianópolis, v.6, n.2, p. 161-190, jul./dez. 2009 
possa estar esse outro, sempre verei e saberei algo que ele próprio, na posição que ocupa, e que o situa fora de mim e à minha frente, não pode ver: as partes de seu corpo inacessíveis ao seu próprio olhar (...), são acessíveis a mim e inacessíveis a ele" (BAKHTIN, 1997, p. 43)

Despertar o interesse do outro por sua vida particular se tornou uma espécie de termômetro para analisar seu valor como pessoa. O valor e a autenticidade do indivíduo não estão mais em sua interioridade, mas no que está exposto e acessível a todos. Um sintoma bem típico desse complexo tem sido observado na medicina estética. Há mulheres lindíssimas, perfeitas, mas que se deprimem por algum detalhe de seu corpo, aparentemente perfeito. É um caso que resvala no psicossomatismo. O alívio para o incômodo só é alcançado quando o cirurgião plástico muda a parte do corpo originalmente natural.

Essa necessidade, às vezes desesperada, de se ver no outro, de ver sua validação na alteridade, apenas nos denota que passamos de uma sociedade disciplinar, como observa Foucault (2000), para a conjuntura que Deleuze (1990) chamou de sociedade de controle. Pelo princípio da exotopia, eu apenas posso me conhecer por inteiro com a ajuda do olhar do outro. Isso indica que tanto eu posso olhar quanto ser olhado. Se minha exotopia (posição exterior) me dá o privilégio de ver o outro, esta visão externa também pode determinar minha posição, afinal, não posso agir como se os outros não existissem. Essa visão "vigiadora" sobre nossa vida faz com que nossas ações sejam representadas do modo como somos vistos por outros.

$\mathrm{Na}$ contemporaneidade, a punição abriu espaço para o controle sutil, manipulando o homem através das instituições, das necessidades supérfluas, dos ditames do capitalismo, dos modelos exibidos pela mídia e sobretudo da necessidade de visibilidade e validação do eu pelo outro. O objetivo do blogueiro é, a priori, alcançar visibilidade. Este na verdade é um objeto, uma vez que sua autêntica pretensão, o valor investido nesse objeto, é saciar ou tentar resolver seu "Complexo do espelho, espelho meu". É um sujeito que busca muito mais o desejo do que o objeto desejado. A visibilidade é uma compensação para preencher um vazio, a falta de reconhecimento, a falta de ser alguém. Com essa sentença, atentando para o valor investido em seu objeto-valor, compreendemos o

R. Inter. Interdisc. INTERthesis, Florianópolis, v.6, n.2, p. 161-190, jul./dez. 2009 
comportamento das jovens que se expõem nos fotologs para ganhar a fama, como vimos no início deste item, ao comentar informes do jornal. O complexo virou uma necessidade, como pronuncia a jovem: "É uma questão de necessidade mesmo."

Essa necessidade gera um grande paradoxo. A exibição da vida íntima denota uma valorização do "eu", contraposta ao menosprezo dos ideais coletivos. Isso é o que vem acontecendo hoje, conforme demonstrou Cortina (2006) no levantamento dos livros mais vendidos ao longo das décadas de 1960 a 2000, quando constatou um predomínio acentuado dos livros de auto-ajuda frente a um desinteresse dos livros cuja temática era social. "O isolamento em que estão colocados os sujeitos do mundo capitalista moderno faz com que ele se volte para si mesmo e, para compreender-se, busque em algum lugar as respostas para suas dúvidas." (p. 101).

Enquanto o homem se volta aos seus interesses privados, à hipertrofia do ego, ele busca o reconhecimento do outro para alimentar seu próprio "eu". Até mesmo Tocqueville, em Democracia na América, atentava para o perigo de uma democracia equacionada na igualdade, porque nesse sistema as intimidades da vida ganhariam uma importância crescente. E ganhou. Os vaticínios foram certeiros.

\section{LIBERDADE}

Roberto Carlos em detalhes, título do livro escrito pelo jornalista Paulo César de Araújo, foi mais que uma biografia, foi uma análise crítica da trajetória de um artista musical e de toda sua obra. Mas o "rei" não permitiu que o livro fosse comercializado. A biografia de 500 páginas, com tiragem de mais de $10 \mathrm{mil}$ exemplares, foi recolhida sob ordem da Justiça, mediante ação movida pelos advogados de Roberto Carlos. São toneladas de papel a serem queimadas e todo um trabalho de pesquisa desperdiçado. O trabalho de um biógrafo foi jogado; papéis, desperdiçados! E o que mais nos incomoda? Os detalhes de uma vida misteriosa.

A proibição do livro acabou provocando uma corrida desenfreada em busca da obra. Muito mais atrativa foi a proibição do que a trajetória profissional do artista. O que há por trás desse livro? Quais os detalhes que mexeram com Roberto?

R. Inter. Interdisc. INTERthesis, Florianópolis, v.6, n.2, p. 161-190, jul./dez. 2009 
Esse incidente envolvendo o cantor Roberto Carlos, em abril de 2007, revigora a antiga idéia da sociedade como um teatro, a qual analisa o comportamento do homem na sociedade como papel de um ator, ou seja, o homem figura como criatura de máscara, com comportamentos específicos para cada situação. Roberto Carlos tem medo de revelar suas verdadeiras posturas? Ele finge ser hoje o que verdadeiramente foi outrora?

Outro episódio, também ocorrido em 2007, causou surpresa mundial, sobretudo na comunidade judaica. O rabino Henry Sobel foi preso em flagrante depois de furtar quatro gravatas em lojas luxuosas de Palm Beach, nos Estados Unidos (EUA). Esse incidente nos remete novamente às relações entre a vida e o palco, assim como defendia Luigi Pirandello, escritor de relevo para a arte dramática.

Em suas peças, a exemplo do que acontece em Seis personagens à procura de um ator, salta aos olhos a demonstração de que a vida é uma farsa, porque na vida real o ser humano, assim como o ator no palco, exerce um papel: pessoa e personagem se confundem. Mas essa não é uma idéia inaugurada por Pirandello. Platão já contemplava a vida humana como um espetáculo de fantoches encenado pelos deuses. E na Idade Média, o mundo, uma espécie de teatro, era visto por uma platéia composta por um único espectador, a figura divina, que vigiava dos céus seus filhos se mascararem na baixa terra.

Portanto, o paradoxo entre o instinto e a convenção é notório. De um lado, um sujeito que quer renunciar (não-querer-ser) às regras sociais, mas necessita (deverser) conservá-las para viver em grupo. Quem pode nos ajudar a entender um pouco essa relação conflitante entre o individual e o social é a Psicanálise.

Freud já dizia que a civilização se baseia na permanente subjugação dos instintos humanos. Se cada um fosse atender ao seu instinto - a força que o move instintivamente -, o convívio civilizado seria impossível, pois o homem, tanto no corpo quanto nas funções fisiológicas, pertence ao reino animal. A chamada pulsão, a força que o impulsiona, é um "processo dinâmico que consiste numa pressão ou força (carga energética, fator de motricidade) que faz o organismo tender para um objetivo" (LAPLANCHE, 2001, p. 394). O progresso está vinculado a uma intensa anulação dessa pulsão instintiva, pois "a livre gratificação das necessidades

R. Inter. Interdisc. INTERthesis, Florianópolis, v.6, n.2, p. 161-190, jul./dez. 2009 
instintivas do homem é incompatível com a sociedade civilizada: renúncia e dilação na satisfação constituem pré-requisitos do progresso." (MARCUSE, 1978, p. 27)

Para uma sociedade civilizada, é necessário o abandono ou conversão dos impulsos animais (princípio do prazer) para instintos humanos (princípio de realidade): da satisfação imediata para a satisfação adiada, do prazer à restrição do prazer.

Esses estágios, princípios de prazer e de realidade, são parecidos com a dicotomia inconsciente (força herdada e primária) e consciência (força adquirida e secundária), instâncias opostas que formam o aparelho mental. Inconsciente é uma dimensão profunda, responsável pelos impulsos irracionais que exigem liberdade e felicidade, motivo pela qual Lévi-Strauss o chamou de "pensamento selvagem". Daí dizer que "ser é, essencialmente, lutar pelo prazer" (MARCUSE, 1978, p. 118). A consciência, por sua vez, reprime esses instintos, pois é uma instância formada ao longo da vida, materializando-se nas convenções e na visão de mundo do homem.

Essa passagem pelas bases da Psicanálise nos ajuda a entender um pouco ações que nem mesmo quem a comete pode explicar, como foi o caso do rabino Henry Sobel, que até hoje tenta se explicar para provar que não é ladrão.

\subsection{0 carnaval}

Se a bipartição é a tônica, cumpre trazer à baila as festas carnavalescas, uma herança das festas saturnais. Instituídas no Império Romano, evocando e enaltecendo Saturno, as festas saturnais eram repletas de alegria, simulando um mundo às avessas.

O carnaval, festa popular que se contrapunha à visão séria das autoridades, tornou-se a expressão mais completa e mais pura da cultura cômica popular, na qual o povo tinha oportunidade de extravasar, de se libertar de um mundo regulamentado e de vencer o medo. Daí o uso de máscaras monstruosas para zombar e exorcizar os temores e os tabus. Por isso, o riso carnavalesco é uma paródia pelas fantasias. Se anteriormente nos referimos às máscaras no sentido figurativo, ao construir a metáfora da vida como um teatro, no carnaval ela se torna um peça real.

R. Inter. Interdisc. INTERthesis, Florianópolis, v.6, n.2, p. 161-190, jul./dez. 2009 
Essas festanças foram descritas por Mikhail Bakhtin (1999) ao fazer menção a François Rabelais, escritor francês considerado o "Voltaire" do século XVI.

Toda a manifestação rabelaiseana é fruto daquilo que Bakhtin chamou de "realismo grotesco", o mundo híbrido das festividades carnavalescas, cujo princípio era a degradação do sublime, com foco na vida material e corporal: imagens do corpo, da bebida, da comida, da satisfação das necessidades naturais e da vida sexual. Havia um processo de rebaixamento: o alto pelo baixo. Nessa inversão, o elevado e o sublime passam para o baixo corporal, explorando processos biológicos fundamentais: absorção dos alimentos, excreção, sexo, odores, flatulência, sujeira, enfim, todas as funções que rebaixam o homem do plano elevado, espiritual, ideal e abstrato para o plano material e corporal, sobretudo erótico.

O homem da Idade Média participava de duas vidas: a oficial, assentada nas normas e nas convenções do cotidiano, e a carnavalesca, sazonal e cômica, funcionando como uma segunda vida, a não-oficial, um momento de liberdade para o povo viver uma vida momentaneamente desregrada. "A segunda vida, o segundo mundo da cultura popular constrói-se de certa forma como paródia da vida ordinária, como um mundo ao revés". (BAKHTIN, 1999, p. 10). Essa segunda vida, vivida durante as festas populares do carnaval, era representada pela máscara, que "é a expressão das transparências, das metamorfoses, das violações das fronteiras naturais, da ridicularização, dos apelidos. [...] a máscara recobre a natureza inesgotável da vida e seus múltiplos rostos". (p. 35)

Com o advento do blog, nós revivemos esse carnaval igualmente com duas vidas: a social ou pública e a particular ou natural. Chris DeWolfe, criador do portal MySpace (site de relacionamentos criado em 2004), ao falar do futuro da internet (BERGAMASCO, 2008, p. F3), destaca três tendências: (i) internet cada vez mais pessoal; (ii) mais portátil; (iii) e mais colaborativa. A primeira tendência a que se refere DeWolfe - personalização - é a segunda vida da qual fala Bakhtin: a vida particular. "Queremos possibilitar que as pessoas coloquem no MySpace tudo aquilo de que gostam na internet.", enfatiza o criador do portal.

Aí reside o grande paradoxo do blog: trata-se de um modo de enunciação que valoriza a intimidade no espaço público, uma espécie de privatização desse espaço, atravessado pelo olhar alheio. Um jogo entre a publicização de si e a intimidade

R. Inter. Interdisc. INTERthesis, Florianópolis, v.6, n.2, p. 161-190, jul./dez. 2009 
construída com os leitores. A fronteira entre espaços público e privado se tornou muito tênue.

O escrevente e o leitor de blog incorporam o espírito dionisíaco, com a estética da liberdade, sobrepondo-se ao espírito apolíneo, o mundo da norma. É o individual em contraposição ao social. Na mitologia grega, Dioniso, ou Baco em latim, é o deus do êxtase (transbordamento da emoção) e do entusiasmo (penetração de deus na alma humana), e também conhecido como o deus do vinho. Ele nega o metron (equilíbrio) e traz o desregramento.

À luz de sua existência modal, temos um sujeito que descobre uma forma de não mais se submeter à necessidade (dever-ser) do dizer social, ou seja, um discurso que não deve fugir às convenções. Agora, o sujeito pode renunciar (nãoquerer-ser) ao dizer regrado para dizer livremente. É um sujeito que não mais quer ser regrado.

Do ponto de vista das modalidades atualizantes, que qualifica o sujeito para uma ação, analisando toda essa mudança, verificamos uma transformação. Temos inicialmente um sujeito impotente (não-poder-fazer), em virtude do monopólio da mídia, impossibilitado de se expressar da forma como gostaria. Quando se expressa, seu dizer se enquadra dentro daquilo que "se deve dizer", ou seja, obedecer às convenções. Com o blog, passamos a ter um sujeito livre (poder-fazer).

\subsection{Pseudoliberdade}

Até aqui, discutimos a dicotomia público versus privado. Mas não tocamos na questão mais delicada: o conceito de liberdade. Não só o blogueiro mas o internauta como um todo se vangloria muito por ter conquistado a liberdade. Além do blog, como vimos nas análises, outra ferramenta que muito enfatiza essa prerrogativa tem sido o Second Life. Mas será que realmente há liberdade?

No blog, temos sim um espaço sem precedentes. Mas a liberdade não é total, é relativa. Assim como no carnaval, é um espaço de liberdade para uma atividade momentaneamente desregrada. Por dois motivos. Primeiro, pela censura. Ainda que rara, ela pode acontecer. O blog é um meio através do qual o blogueiro tem liberdade para dizer o que quer, da forma como o quer. Mas se cometer algum

R. Inter. Interdisc. INTERthesis, Florianópolis, v.6, n.2, p. 161-190, jul./dez. 2009 
crime, sua página será tirada do ar. Valem para os blogs as mesmas restrições legais que se aplicam a outros veículos de comunicação.

Um caso extremado, mas que infelizmente ocorre, é quando pessoas praticam pedofilia pela rede. Até que sua ação não seja descoberta, seu comportamento é realizado a seu bel-prazer, de forma desregrada. A partir do momento, porém, que a infração vem à tona, ele sofre as penas cabíveis. A mesma coisa aconteceu no episódio do vídeo da modelo Daniella Cicarela, exibido no YouTube. Por ação movida pelo advogado da artista, a página ficou vários dias fora do ar, causando a revolta de muitos internautas.

Como se pode ver, a liberdade que tanto se prega entre os blogueiros é relativa. Aí voltamos àquilo que Freud disse: a civilização se baseia na permanente subjugação dos instintos humanos. Pelo ponto de vista da modalidade veridictória, a liberdade apregoada é uma mentira. Temos no eixo da manifestação (aparência) um bloguerio que parece-ser livre. Mas no eixo da imanência (essência) ele não-é livre.

O segundo motivo pelo qual podemos dizer que o blog não goza de total liberdade é por conta da cumplicidade.

Tanto nos posts quanto nos comentários inseridos pelos leitores, essa "liberdade" é colocada como patente, sobretudo quando verificamos a linguagem pela qual são escritos: "Oie! Lindu seu blog! E essa musik do legião eh xoww bom fim d smna bjujus". Nesse comentário, verificamos o uso do internetês, com abandono das regras do idioma e infração à gramática, imperando uma formulação própria de linguagem: "xoww" (em vez de "show"); smna (semana); bjujus (beijos). Criou-se um novo código, o código virtual do internetês, em que não há respeito à pontuação tampouco à ortografia. O proibido é permissível; o anormal é normal; o espampanante é risível. A página se transforma num palco onde qualquer peça é um espetáculo. A beleza das palavras dá lugar ao espandongamento. Até parece que os blogueiros escrevem como uma forma de extravasar as "torturas" sofridas no colégio quando das aulas de português!

O "novo código" do qual falei é apenas um exemplo da maneira por que entre os blogueiros foi estabelecido um novo comportamento, uma nova maneira de ser

R. Inter. Interdisc. INTERthesis, Florianópolis, v.6, n.2, p. 161-190, jul./dez. 2009 
que construiu uma identidade, uma cumplicidade. Quem não estiver nos moldes desse comportamento, é considerado um estranho no ninho.

Dessa forma, por trás do aparente desregramento foi edificado um novo regramento. Para pertencer a essa "tribo" é preciso viver como eles, é preciso falar como eles, é preciso ler como eles, enfim, é preciso ser como eles.

Discorrer sobre liberdade não é uma tarefa fácil, a começar pelas suas várias conotações tanto verticais (histórica) quanto horizontais (presente). Na Grécia Antiga, liberdade continha um sentido político. Ser livre era poder participar das decisões políticas na Polis. Liberdade, portanto, era sinônimo de cidadania. O Cristianismo desloca a liberdade para o interior de cada um, quando apregoa que o homem livre é aquele que pode escolher entre o bem e o mal. Essa despolitização da liberdade, ao interiorizá-la, provoca também sua moralização. Torna proibida a autonomia, subordinando a vontade humana à outra vontade, a vontade de Deus. Ser livre é poder obedecer aos comandos divinos. Com a chegada da Idade Moderna, o capitalismo acaba regendo todo o conceito de liberdade. $O$ indivíduo livre é membro de um novo centro organizador, o mercado. O que impulsiona o homem são os interesses pragmáticos, que se tornam o centro da racionalidade moderna.

Ainda que elenquemos esses vários sentidos dessa nomenclatura, certamente a deixaremos incompleta por conta de sua complexidade, amplitude e vagueza. Talvez o fato de proclamar a usurpação da liberdade esteja na vontade sepultada de vingar a derrota nas três principais frustrações por que passou o homem ao longo do tempo no tocante à liberdade. Foram três golpes que afetaram a vaidade humana.

A primeira veio com o astrólogo polonês Nicolau Copérnico (1473-1543), que desmoronou a teoria do astrônomo grego Cláudio Ptolomeu (séc. II d.C), ao defender a tese de que não são os astros que giram em torno da Terra, como propunha Ptolomeu, mas os planetas que giram em torno do Sol. Fomos forçados a admitir que nosso planeta é apenas um dentre os que giram ao redor do Sol, e que há outros sistemas além do nosso, em incontáveis mundos. Essa asserção revolucionou a forma de pensar o homem no mundo, pois minou a idéia de que o

R. Inter. Interdisc. INTERthesis, Florianópolis, v.6, n.2, p. 161-190, jul./dez. 2009 
homem é o centro do universo, que todos os corpos celestes giravam ao nosso redor. Ele é apenas parte dele.

A segunda grande frustração veio com o naturalista inglês Charles Darwin (1809-1882), que chegou a conclusão de que há um parentesco fisiológico e uma origem comum entre todos os seres vivos, com a formação de novas espécies por um processo de seleção natural. Nosso organismo físico é o produto de um vasto processo evolutivo, cujas leis em nada diferem daquelas dos animais. Com isso, corrobora-se a idéia de que somos primatas, uma espécie vinda dos macacos. A crença de que seríamos uma espécie única, completamente separada do reino animal, definhou.

Por fim, a terceira e derradeira frustração por que passa o homem procede de Sigmund Freud (1856-1939), que expõe a dualidade do homem - consciência e inconsciente - , conforme expusemos sucintamente acima. $O$ homem acreditava que o que dizia e fazia era produto de sua vontade consciente. Mas a existência de outra parte de nossas mentes, que funciona no mais obscuro segredo e que pode até comandar nossas vidas, era desconhecida. Freud iluminou essa escuridão e abriu caminho para a investigação dos mistérios do homem.

A descoberta do inconsciente fez com que o conceito de "liberdade" ficasse relativizado. Com a idéia de um indivíduo bipartido, "a verdadeira liberdade está só na idéia. Assim, a libertação é um evento espiritual". (MARCUSE, 1978, p. 113). Baudrillard (2002, p. 132) repisa a pseudoliberdade, dizendo que "a internet apenas simula um espaço de liberdade e de descoberta".

Dessa forma, o homem racional do qual nos fala Descartes, com pleno poder de decidir completamente seu destino, é uma quimera. Há um feixe de desejos e impulsos, e outras motivações, de que à vezes não temos consciência. É justamente a luta da força do instinto individual contra as injunções éticas, religiosas e sociais que tenta explicar a Psicanálise, ao investigar a atividade do inconsciente. E a grande contribuição de Freud, longe de querer reduzir um teórico tão dinâmico e completo, consistiu em ampliar a esfera da personalidade humana, descobrindo a dimensão misteriosa e tão profunda do inconsciente. Pela visão da Psicanálise, portanto, não existiria liberdade, porque somos determinados pela força do

\footnotetext{
R. Inter. Interdisc. INTERthesis, Florianópolis, v.6, n.2, p. 161-190, jul./dez. 2009
} 
inconsciente. O homem viveria uma "sensação ptolemaica", porquanto não é mais o centro.

\subsection{Dialogismo}

Como nós teríamos liberdade se o que pensamos é fruto do nosso vínculo com o passado, com o que recebemos de nossos pais e com quem nos rodeia. Conforme dizia Goethe, "o que pensas pertence a todos; só é privativamente teu o que sentes". O nosso interior é formado pela exterioridade, como muito bem nos demonstrou Kaspar Hauser (1974), que no isolamento do cubículo, privado da convivência com o mundo, era desprovido até mesmo de pensamento. Esse vazio se deve porque a consciência e a própria compreensão de mundo só podem surgir e se afirmar mediante a linguagem e o processo de interação social, porque nossa consciência é um produto sócio-histórico. As bases do nosso pensamento não são fisiológicos nem biológicos, mas sociológicos, porque "o homem deve necessariamente ser social para ser homem". (BONCINELLI, 2007, p. 16).

Assenhoreando o princípio dialógico de constituição da linguagem, que diz fundamentalmente que nosso discurso é formado pelos outros discursos que nos precedem, inseridos numa interação social, podemos afirmar que nós também somos, assim como nosso discurso, fruto da relação social. Se o discurso é social, a sua fonte de inspiração, nossa consciência, igualmente o é. Nossa consciência é formada a partir da linguagem e da prática social num processo de interação.

Sendo nossa consciência social, advinda dos outros, nossa forma de pensar e o que pensamos é uma herança. Se o pensamento é uma herança que ilusoriamente pensamos ser apenas nossa, nossas idéias não são nossas; são dos outros.

Com isso, somos produto da prática social. Nessa relação não há ativos ou passivos, porque ambos produzem. No clássico modelo do sistema geral de comunicação, proposto por Shannon (WOLF, 2002, p. 113), a transferência de informação se realizava da fonte de informação (emissor) para o destinatário (receptor), representando o destinatário apenas um elemento passivo de recebimento da mensagem.

R. Inter. Interdisc. INTERthesis, Florianópolis, v.6, n.2, p. 161-190, jul./dez. 2009 
Mas como pode ele ser passivo se o discurso é construído em razão daquele que receberá a mensagem? Aquele a quem me dirijo determina a forma e o conteúdo do que vou dizer. "Essa orientação da palavra em função do interlocutor tem uma importância muito grande. Na realidade, toda palavra comporta duas faces. Ela é determinada tanto pelo fato de que procede de alguém, como pelo fato de que se dirige para alguém". (BAKHTIN, 1992, p. 113). Além de o outro determinar meu discurso, é ele também quem forma o meu discurso. "O enunciado está repleto dos ecos e lembranças de outros enunciados, aos quais está vinculado no interior de uma esfera comum da comunicação verbal" (BAKHTIN, 1997, p. 316).

Nos estudos bakhtinianos, nos quais o enunciado é considerado a unidade da comunicação verbal, o discurso é entendido como um elo de uma cadeia, estando sempre ligado aos discursos que o precedem e aos que o sucedem. Como na forma clássica do diálogo, metáfora da qual Bakhtin se vale para explicar a teoria do dialogismo, todo discurso é sempre uma resposta a outros discursos. O diálogo, na sua forma restrita de comunicação interpessoal, é uma figura pertinente para entendermos lato sensu o funcionamento de toda forma de comunicação: verbal, não-verbal ou sincrética. Nesse raciocínio, não há como dizer que haja um discurso proferido pela primeira vez, porque ele sempre será uma resposta ao que foi dito. Não há discurso puro, originalmente inédito. Nenhum discurso nasce do nada. "Um locutor não é o Adão bíblico, perante objetos virgens, ainda não designados, os quais é o primeiro a nomear." (BAKHTIN, 1997, p. 319). Sempre há informações que o precedem, vindas de outras fontes. Pelo princípio do dialogismo, portanto, poder dizer o que quer não basta para alcançar autenticamente a liberdade.

Impossível ser totalmente livre se o que pensamos é resultado da interação com o mundo. Quem goza de total liberdade é quem sofre da demência, da esquizofrenia, quem vive num mundo à parte. Apenas o louco seria livre. Nossa liberdade é antes uma pseudoliberdade. Infelizmente vivemos ainda o pseudoptolemaiquismo. O mais correto seria dizer que temos uma liberdade condicionada.

Condicionada por nosso inconsciente, por nossa ideologia, por nossos desejos mais escamoteados. E também porque a liberdade do blogueiro agora está

R. Inter. Interdisc. INTERthesis, Florianópolis, v.6, n.2, p. 161-190, jul./dez. 2009 
condicionada a duas novas pressões: ideologia do laxismo e necessidade de atualização para se manter sempre visto.

\subsection{Ideologia do laxismo}

Dizer que com o blog o diarista alcançou total liberdade igualmente constitui uma mentira. Sua liberdade parece ter sido conquistada, mas não foi. Em sua essência, o dizer do blogueiro é condicionado pelo que eu chamo de "ideologia do laxismo". Ele se tornou um dissidente do rigorismo para ingressar no mundo do "faz de conta que sou livre": sem dever nem rigor. É apostasia das normas e apoteose do que "dar na telha".

Segundo Freud (1978), a ideologia é uma servidão voluntária que leva à infantilização do sujeito, pois o impede de pensar para seguir algo maior e supremo. Por isso, diz-se que as utopias são necessárias para suportar o mal-estar da civilização, o sentimento de culpa internalizado em virtude da forte pressão dos interditos que priva o homem de seus instintos, ocasionando-Ihe a renúncia, a insatisfação.

A "ideologia do laxismo" é sua utopia para esconder sua servidão ao que Lipovetsky (1989) chama de "sociedade contemporânea pós-moralista". Há um apagamento do dever e uma afirmação do princípio do prazer, quando os padrões rígidos (moral, religiosa, ético, etc.) são negados. Exalta-se o hedonismo. O homem contemporâneo não vive mais sob a pressão do dever disciplinador. Agora, é proibido ser sério. Diante dessa nova exigência, a liberdade de que parece gozar é irreal.

O estado de tranqüilidade do blogueiro sofre a ameaça da necessidade da atualização. Esta é outra pressão a que ele se submete. O blog que deixa de postar texto gera desinteresse em seus leitores. Blog desatualizado é blog abandonado. Quem quer manter seus leitores, ter expressivo número de acessos e poder segurar a "fama", precisa religiosamente postar todos os dias na sua página. Para manter a visibilidade e, portanto, a funcionalidade enquanto sujeito satisfeito, o blogueiro necessita da atualização constante. Isso acaba virando um drama, porque nem sempre tenho algo a falar. Se o blogueiro é obrigado a expor algo, nem sempre esse

R. Inter. Interdisc. INTERthesis, Florianópolis, v.6, n.2, p. 161-190, jul./dez. 2009 
algo terá relevância. Para ser atrativo para a audiência, o blogueiro se utiliza de assuntos variados, abordando de forma lúdica, irônica, leve. Busca sempre a descontração fazendo do blog uma espécie de espaço de lazer. Daí é que surge o estilo lúdico, assunto que discutiremos a seguir.

\section{Ludicidade}

Baudrillard (1994, p. 15) ridicularizava a massa quando dizia que ela prefere trocar uma manifestação política importante por um jogo de futebol na televisão. Nessa conjuntura, o filósofo predisse o fim do social, com falência de todos os poderes e saberes que pretendessem absorver as massas. Elas não querem saber da seriedade da comunicação racional das mídias. Elas querem espetáculo. É o espetáculo que comanda as ações da mídia: "o espetáculo é a ideologia por excelência, porque expõe e manifesta em sua plenitude a essência de todo sistema ideológico: o empobrecimento, a sujeição e a negação da vida real." (DEBORD, 1997, p. 138).

Por que um total descaso para assuntos e fatos de suma importância e um frenesi por conteúdos irrelevantes para nossas vidas, que em nada acrescentará para nosso desenvolvimento? Por que chegamos a uma "sociedade da banalidade"?

\subsection{Pós-modernismo}

As mudanças pelas quais passamos são consequências daquilo que se convencionou chamar de pós-modernismo. Há dificuldade em compreender o significado do termo, por ser adotado nas mais diversas áreas, de comportamentos e alimentação até os complexos problemas de ordem epistemológica.

Para Giddens (1991), há uma distinção entre pós-modernidade e pósmodernismo. Este se refere a estilos ou movimentos dentro da literatura, artes plásticas e arquitetura, sendo uma reflexão estética. Aquele é a fase para a qual estamos caminhando, baseada numa nova e diferente ordem social. Segundo Giddens (1991), não vivemos ainda num universo pós-moderno porque não saímos

R. Inter. Interdisc. INTERthesis, Florianópolis, v.6, n.2, p. 161-190, jul./dez. 2009 
da modernidade. Vivemos, na verdade, a fase de radicalização do período moderno, fase esta que Giddens chama de "alta modernidade". De acordo com Guelfi (1994), pós-modernismo não é um período ou um estilo, mas um amplo movimento intelectual de questionamento da modernidade.

O modernismo privilegia o universal e a racionalidade, acreditando no progresso linear da civilização, no engajamento de valores, na continuidade temporal da história, no planejamento racional e duradouro da ordem social, política e cultural. O pós-modernismo, ao contrário, adota uma postura inversa: privilegia a heterogeneidade e a diferença; contra a tendência da totalidade, enfatiza o pluralismo, a fragmentação, a indeterminação e a descontinuidade do tempo. Com a destemporalização, vive-se um eterno presente e a perda do sentido histórico, coabitando tempos heterogêneos e pluralidade de estilos.

O pós-modernismo, pois, cultiva o descompromisso com projetos estéticos e ideológicos, a pluralidade e os novos usos da linguagem. Lipovetsky (1989) diz que na sociedade pós-moderna há um novo modo de se organizar e se orientar. Em primeiro lugar, não há mais uma ideologia como rumo. É o vazio quem nos governa. Ninguém espera o futuro; querem viver o já, mergulhado no Carpe Diem.

\subsection{Quixotismo às avessas}

O que diria nosso honrado fidalgo Quixana, um simplesmente Dom Quixote, uma figura ilustre da ficção espanhola, imortalizado pela literatura universal, que inspirou muitos personagens, desde sua criação, em 1604. Para Quixote, dignas de divulgação seriam as ações heróicas. Do contrário, atos degradantes deveriam ser rechaçados:

\footnotetext{
Uma das coisas que devem dar maior satisfação a um homem honrado e eminente - emitiu Dom Quixote - é ver-se em vida celebrado em letra redonda e andar, com boa fama, na boca de tanta gente e falando tão desvairados idiomas. Disse boa fama, porque sendo o contrário, não há morte que the iguale. (CERVANTES, 1963, p. 26)
}

As vulgaridades da mídia e muitos dos blogs que analisamos figuram, de acordo com os ensinamentos de nosso fidalgo, como aquilo que defino como Quixotismo às avessas.

R. Inter. Interdisc. INTERthesis, Florianópolis, v.6, n.2, p. 161-190, jul./dez. 2009 
Quixotismo recebeu uma conotação pejorativa, que nos remete ao idealismo ou à ingenuidade. Mas permite também que usemos a conotação positivamente, como sinônimo de ações de prestígio. É para essa direção que dirijo a cunhagem de minha expressão. Sigo o raciocínio de tanto o enunciador de blog desenvolvem uma enunciação não muito preocupada com o prestígio e com a beleza. Daí tais blogs seguirem um princípio contrário ao de Dom Quixote. Podemos dizer que o blogueiro é o oposto do que anunciava o cavaleiro da triste figura: "é o meu ofício e exercício andar pelo mundo endireitando tortos, e desfazendo agravos". (CERVANTES, 1981, p. 105).

Quixote alimentava o desejo de sua figura ser vista e lembrada por atos positivos e dignos de honra: "Ditosa idade e século ditoso, aquele em que hão de sair à luz as minhas famigeradas façanhas dignas de gravar-se em bronze, esculpirse em mármores, e pintar-se em painéis para lembrança de todas as idades" (CERVANTES, 1963, p. 33). É exatamente o contrário do que impulsiona a prática dos blogueiros: falem bem ou mal, o que importa é que falem de mim!

O fenômeno do "Quixotismo às avessas" é uma forma de figurativizar aquilo que julgo ser o termo sintetizador de um das características do blogueiro: ludicidade. Ao lado de narcisismo e liberdade, coloco "ludicidade" como o terceiro pilar sobre os quais se assenta o perfil do blogueiro.

Ludicidade proporciona ao blog leveza. Página atrativa e com audiência é aquela que consegue imprimir ao post um tom leve e ao mesmo tempo divertido. A discussão árida (problemas sociais ou ambientais como, por exemplo, as soluções para o fim do tráfico de animais silvestres) é substituída por fatos corriqueiros ou curiosos (como foi a visita do presidente a uma festa), envolvidos na sátira e na ironia. O leitor de blog busca entretenimento na abordagem de um fato. Ele quer a informação sempre de um ponto de vista cômico. Ainda que um blog forneça dados importantes, a discussão deve ser feita de forma descolada. Na imprensa tradicional, a prioridade é a busca por um saber. No blog, o leitor tem uma postura diferente. A busca por um saber é secundária. A ordem dá lugar ao caos. E a dominante passa a ser o despropósito e o tom lúdico.

Wagner Martins, editor do site Cocadaboa, elenca três receitas para o sucesso de um blog: atualidade, paixão e humor (FREITAS, 2006). O efeito de

R. Inter. Interdisc. INTERthesis, Florianópolis, v.6, n.2, p. 161-190, jul./dez. 2009 
sentido do riso é uma constante. Às vezes, esse riso é colocado de forma inteligente, como no caso de Noblat. Nele a ludicidade se faz por meio da ironia. Por isso, prefiro dizer que o riso é sinônimo de leveza, enquadrando-o dentro das características do lúdico.

Nos outros blogs analisados, entretanto, a única "ação heróica" tem sido manter as visitas e a visibilidade da página. Fora isso, são colocações que deixariam Santo Agostinho boquiaberto. Tive a oportunidade de me deparar com um blog que exibia a foto de seu autor completamente nu correndo sobre um skate. Abaixo da imagem, um comentário. Fora colocada aquela imagem apenas para não deixar de inserir um post naquele dia. Por falta de algo mais interessante, ele resolveu surpreender para não "esfriar" sua página. Nosso Dom Quixote jamais preencheria sua página com alguma vulgaridade, tão-somente com a desculpa de se manter atualizada: "Caminhou quase todo o dia sem lhe acontecer coisa merecedora de ser contada; com o que ele se amofinava, pois era todo o seu empenho topar logo logo onde provar o valor do seu forte braço" (CERVANTES, 1963, p. 33)

Como aponta Lemos (2002, p. 12), neste novo meio "a máxima é: 'Minha vida é como a sua, logo tranqüilize-se, estamos todos na banalidade do quotidiano'”. Disso, parafraseando Descartes, entendemos que a lógica que impulsiona o blog é: "sou visto, logo existo".

\section{CONSIDERAÇÕES FINAIS}

Como podemos entender o homem contemporâneo? Para buscar uma expressão que abarcasse toda nossa conjuntura volátil, escorregadia, várias foram as denominações: pós-modernismo, supermodernidade, modernidade tardia, alta modernidade, segunda modernidade. Bauman (2001) passa ao largo da preocupação de discutir a expressão mais coerente. Simplesmente usou como alegoria a fluidez a fim de retratar o período em que vivemos como "líquido", que se substitui à "solidez" da fase anterior, com visão racionalista, universal e totalizante, engajada em valores e enraizada em perspectivas históricas e vindouras. Ao contrário, a era contemporânea "efetivamente envolve a institucionalização da dúvida". (GIDDENS, 1991, p. 175).

R. Inter. Interdisc. INTERthesis, Florianópolis, v.6, n.2, p. 161-190, jul./dez. 2009 
Os sólidos têm forma fixa, enquanto os fluidos podem tomar qualquer forma, adaptam-se conforme os contornos para onde vai ou mudam dependendo da pressão à qual são submetidos. Assim, o líquido não se apega a um corpo estável; está sempre pronto para mudar.

llustrando com a fluidez a conjuntura na qual vivemos, Bauman (2001) utiliza a expressão "modernidade líquida". A força desse fenômeno produziu mudanças profundas no ser humano, já que seu comportamento é fruto das circunstâncias que a vida social o possibilitou. A nossa interioridade é efeito de tudo aquilo que nos toca.

Assim, a internet foi uma circunstância criada pelo desenvolvimento tecnológico que, pela sua própria condição, a navegação pelo mundo todo a partir de um terminal de computador, introduziu uma nova forma de conhecer o mundo. $O$ desprendimento que o mundo virtual proporcionou, um "não-lugar" - se comparássemos com o conceito de Auge (1994), que fala da passagem dos lugares que produziam memórias extensivas para os não-lugares das intensidades breves -, refletiu no blogueiro como "efeito colateral" a transitoriedade, a possibilidade de mudança.

Uma das características da era contemporânea é o extremo dinamismo, intimamente associado à idéia de leveza. O leve se desloca com facilidade. Blogs são leves, deslocam-se. Hoje crio uma página. Amanhã a abandono. Os blogs que aqui analisamos podem amanhã estar fora de funcionamento, sem atualização. Outros blogs podem conquistar a atenção dos leitores. Não se espera mais a duração eterna. "As comunidades em questão tendem a ser voláteis, transitórias e voltadas ao 'aspecto único' ou 'propósito único'. Sua duração é curta, embora cheia de som e fúria". (BAUMAN, 2001, p. 228).

A imagem do leitor se revela tão complexa quanto a própria rede. Mas nesse mosaico de figuras predomina ivariavelmente três características: o desejo de buscar uma identificação com o que lê (narcisismo); a sensação de caminhos sem barreiras (pseudoliberdade); e uma leitura descontraída (lúdico).

Quanto à autoafirmação do indivíduo, os interesses particulares encobrem os interesses coletivos. 'O 'público' é colonizado pelo 'privado'; o 'interesse público' é reduzido à curiosidade sobre as vidas privadas de figuras públicas e a arte da vida

R. Inter. Interdisc. INTERthesis, Florianópolis, v.6, n.2, p. 161-190, jul./dez. 2009 
pública é reduzida à exposição pública das questões privadas e a confissões de sentimentos privados (quanto mais íntimos, melhor)". (BAUMAN, 2001, p. 46). Predomina o discurso que diz aos indivíduos conservarem suas diferenças e escolherem seus próprios modelos. Reflexo disso tem sido a propagação intensiva da autoajuda. Essa "privatização" culmina com uma espécie de "egosurfing", quando a navegação pelos blogs se transforma numa busca do seu próprio "eu". Lendo o diário com o qual tem identidade, o leitor se valida pelo dizer do outro.

A heterogeneidade do leitor de blog corresponde ao seu desejo (querer-ser) de emancipação (poder-fazer) e de desprendimento (querer-não-ser). Para o escritor francês Gilles Lapouge, os atos de viajar e escrever são fundamentais para livrar o homem da terrível condição de viver o dia-a-dia consigo mesmo, do nascimento à morte. A liberdade é encarada como um extravio. "Viajar e criar um mundo ficcional seriam experiências de descentramento. $O$ romancista é alguém que não suporta ser apenas ele mesmo". (ORICCHIO, 2006, p. d6). No heterodoxo caráter do leitor de blog, os diários virtuais são igualmente um "extravio". Transformam-se num caminho paralelo, um metrô que circula à sombra das avenidas a céu aberto, uma segunda vida, a carnavalesca.

A respeito da ludicidade, o leitor quer o discurso que the proporcione uma leitura agradável, ora entretenimento, ora abordagem irônica. A busca da informação (saber) para sair do seu estado de ocultação (não-saber) é um epifenômeno, algo secundário. $O$ sujeito-leitor tem como objeto-valor a descontração. O que importa é a forma como a informação é dada, seu efeito de sentido do riso. Por isso, a construção discursiva está assentada no espírito lúdico.

No filme "O Nome da Rosa" (O NOME, 1986), produção inspirada no romance de Umberto Eco - a narrativa tem como pano de fundo a suposta existência do segundo livro da "Poética" de Aristóteles, que se dedica à comédia -, o bibliotecário cego e cheio de segredos, Jorge de Burgos, terminantemente diz: "Um monge não deve rir. Só os tolos levantam a voz para rir! Esta abadia está à sombra do pesar. A providência não deseja que futilidades sejam glorificadas". O blog são os fundos do monastério, onde o riso "rola solto". Seu leitor passa longe do celibato da seriedade.

R. Inter. Interdisc. INTERthesis, Florianópolis, v.6, n.2, p. 161-190, jul./dez. 2009 


\section{REFERÊNCIAS}

AUGÉ, Marc. Não-lugares: introdução a uma antropologia da supermodernidade. Trad. Maria Lúcia Pereira. Campinas: Papirus, 1994.

BAKHTIN, Mikhail. Marxismo e filosofia da linguagem. 6. ed. Trad. Michel Lahud e Yara Fratesch Vieira. São Paulo: Hucitec, 1992.

. Estética da criação verbal. Trad. Maria Ermantina Galvão G. Pereira. 2. ed. São Paulo: Martins Fontes, 1997.

A cultura popular na Idade Média e no Renascimento: o contexto de François Rabelais. Trad. Yara Frateschi Vieira. 4. ed. São Paulo: Hucitec; Brasília: Editora da Universidade de Brasília, 1999.

BAUDRILLARD, Jean. À sombra das maiorias silenciosas: o fim do social e o surgimento das massas. Trad. Suely Bastos. 4. ed. São Paulo: Brasiliense, 1994.

Tela total: mito-ironias da era do virtual e da imagem. Trad. Juremir Machado Silva. 3. ed. Porto Alegre: Sulina, 2002.

BAUMAN, Zygmunt. Modernidade líquida. Trad. Plínio Dentzien. Rio de Janeiro: Jorge Zahar Editor, 2001.

BERGSON, Henri. O riso: ensaio sobre a significação do cômico. 2. ed. Rio de Janeiro: Zahar, 1983.

BERGAMASCO, Daniel. A Internet vai ficar mais pessoal. Folha de S. Paulo. São Paulo, ano 88, $\mathrm{n}^{\circ}$ 28.826, Caderno Informática, p. F3, 5 mar 2008.

BONCINELLI, Edoardo. Necessidade e contingência da natureza humana.

INTERthesis: Revista internacional interdisciplinar. Florianópolis, v. 4, p. 1-24, jan./jun. 2007.

CERVANTES DE SAAVEDRA, Miguel de. O engenhoso fidalgo Dom Quixote de la Mancha. Trad. Aquilino Ribeiro. $2^{\circ}$ volume. São Paulo: Difusão Européias do livro, 1963.

Dom Quixote de la Mancha. Trad. dos Viscondes de Castilho e Azevedo.

São Paulo: Abril Cultural, 1981.

CORTINA, Arnaldo. Leitor contemporâneo: os livros mais vendidos no Brasil de 1966 a 2004. Tese de livre-docência defendida no Programa de Pós-graduação em Lingüística e Língua Portuguesa da Faculdade de Ciências e Letras da Universidade Estadual Paulista (UNESP), Araraquara, 2006.

R. Inter. Interdisc. INTERthesis, Florianópolis, v.6, n.2, p. 161-190, jul./dez. 2009 
DEBORD, Guy. A sociedade do espetáculo. Trad. Estela dos Santos Abreu. Rio de Janeiro: Contraponto, 1997.

DELEUZE, G. Pós-Scriptum sobre as sociedades de controle. Em: Conversões. Editora 34. Rio de Janeiro, 1990.

FOUCAULT, M. O panoptismo. In: Vigiar e punir: nascimento da prisão. 23.ed.

Trad.: Raquel Ramalhete. Petrópolis (RJ): Vozes, 2000. p.162-192.

FREITAS, Evelson de. Qual é a receita para o boato de sucesso? Agência Estado, São Paulo, 2006. Disponível em:

$<$ http://www.link.estadao.com.br/index.cfm?id_conteudo=6359>. Acesso em: 6 fev. 2006.

FREUD, Sigmund. Cinco lições de psicanálise; A história do movimento psicanalítico; O futuro de uma ilusão; O mal-estar na civilização; Esboço de Psicanálise. Seleção de textos: Jayme Salomão. Trad. Durval Marcondes et al. São Paulo: Abril Cultural, 1978.

FROMM, Erich. Psicanálise da sociedade contemporânea. Trad. L. A. Bahia \& Giasone Rebuá. 2. ed. Rio de Janeiro: Zahar Editores, 1961.

GIDDENS, Anthony. As conseqüências da modernidade. Trad. Raul Fiker. São Paulo: Ed. da UNESP, 1991.

GRIMM, Jacob. Contos de Grimm. Trad. Fernando Klabin. Florianópolis: Ed. Da UFSC, 1998.

GUELFI, Maria Lúcia Fernandes. Narciso na sala de espelhos: Roberto Drummond e as perspectivas pós-modernas da ficção. 1994. Tese (Doutorado) - Departamento de Letras, PUC-RJ, Rio de Janeiro, 1994.

KUNDERA, Milan. A insustentável leveza do ser. 2. ed. Trad. Tereza B. Carvalho da Fonseca. Rio de Janeiro: Nova Fronteira, 1985.

JUNG, Karl Gustav. Tipos psicológicos. Trad. e apresentação de Álvaro Cabral. 4. ed. Rio de Janeiro: Zahar editores, 1981.

LAPLANCHE, Jean. Vocabulário da Psicanálise. Direção de Daniel Lagache. Trad. Pedro Tamen. 4 ed. São Paulo: Martins Fontes, 2001.

LASCH, Christopher. A cultura do narcisismo: a vida americana numa era de esperanças em declínio. Trad. Ernani Pavaneli. Rio de Janeiro: Imago, 1983.

LEMOS, André. A arte da vida: diários pessoais e webcams na Internet. Trabalho apresentado ao Núcleo de Pesquisa Tecnológicas da Informação e da

R. Inter. Interdisc. INTERthesis, Florianópolis, v.6, n.2, p. 161-190, jul./dez. 2009 
Comunicação. In CD-ROM da XXV Congresso Brasileiro de Ciências da Comunicação (INTERCOM), Salvador, 2002, 17p.

LIPOVETSKY, Gilless. A era do vazio: ensaios sobre o individualismo contemporâneo. Trad. Miguel Serras Pereira e Ana Luísa Faria. Lisboa: Relógio d’Água Editores Ltda, 1989.

MARCUSE, Herbert. Eros e civilização: uma interpretação filosófica do pensamento de Freud. Trad. Álvaro Cabral. 7 ed. Rio de Janeiro: Zahar Editores, 1978

MORIN, Edgar. Cultura de massas no século XX: neurose. Trad. Maura Ribeiro Sardinha. 9. ed. Rio de Janeiro: Forense Universitária, 1997. (O espírito do tempo: neurose - volume 1)

O ENIGMA de Kaspar Hauser. Produção de Werner Herzog. Berlim: Werner Herzog Filmproduktion, 1974.

O NOME da rosa. Direção Jean-Jacques Annaud. Berlim: Warner Home Vídeo, 1986.

ORICCHIO, Luiz Zanin. Gilles Lapouge: a liberdade como extravio. O Estado de S. Paulo, São Paulo, Caderno Cultura, p. D6, 29 out 2006.

QUANDO Nietzsche chorou. Baseado no romance Quando Nietzsche chorou, de Irvin Yalom. Escrito, dirigido e produzido por Pinchas Perry: Millennium Films, 2007.

QUINTANA, Mário. Mário Quintana. Seleção de textos, notas, estudos biográficos, histórico e crítico e exercícios por Regina Zilberman. São Paulo: Abril Educação, 1982.

SIBILIA, Paula. A vida como relato na era do fast-forward e do real time: algumas reflexões sobre o fenômeno dos blogs. Em Questã, Porto Alegre, v. 11, n. 1, p. 3551, jan/jun. 2005

TÓFOLI, Daniela. Adolescentes expõem corpos em fotologs na busca da fama virtual. Folha de S. Paulo, São Paulo, ano 86, n. 28.282, 8 set 2006. Cotidiano, p. C4.

VELHO, Gilberto. Individualismo e cultura: notas para um antropologia da sociedade contemporânea. 7. ed. Rio de Janeiro: Jorge Zahar, 2004.

WOLF, Mauro. Teorias da comunicação. 7. ed. Lisboa: Editorial Presença, 2002.

Artigo:

Recebido em: 16/06/2009

Aceito em: 03/11/2009

R. Inter. Interdisc. INTERthesis, Florianópolis, v.6, n.2, p. 161-190, jul./dez. 2009 